Original Research Article

\title{
Comparative clinical profile of patients of Benign Prostatic Hyperplasia (BPH) with and without Metabolic Syndrome: a prospective observational study
}

\author{
Vikrant Panwar $^{1}$, B. L. Pandey ${ }^{1}$, U. S. Dwivedi ${ }^{2}$, Alok Singh ${ }^{1 *}$
}

\begin{abstract}
${ }^{1}$ Department of Pharmacology, ${ }^{2}$ Department of Urology, Institute of Medical Sciences, Banaras Hindu University, Varanasi Uttar Pradesh, India
\end{abstract}

Received: 29 July 2017 Accepted: 23 August 2017

\section{*Correspondence to: \\ Dr. Alok Singh, \\ Email: draloksingh410@ gmail.com}

Copyright: (C) the author(s), publisher and licensee Medip Academy. This is an openaccess article distributed under the terms of the Creative Commons Attribution NonCommercial License, which permits unrestricted noncommercial use, distribution, and reproduction in any medium, provided the original work is properly cited.

\begin{abstract}
Background: Benign Prostatic Hyperplasia (BPH) is one of common disorder in men of old age group. The pathogenesis of BPH is multi-factorial and still not been fully elucidated. There are numerous reports which suggest possible link between several metabolic alterations known as Metabolic Syndrome. In the present study, the aim was to establish relation between Benign Prostatic Hyperplasia and Metabolic Syndrome and to find out effects of therapeutic intervention of Metabolic Syndrome on prostatic parameters.

Methods: 93 patients of Benign Prostatic Hyperplasia enrolled who met qualifying criteria for inclusion in study and divided into three groups on the basis of Metabolic Syndrome and its treatment administered. Administration of alpha adrenergic blocker was common to all patients of all groups. Metabolic parameters including Fasting blood glucose, High-density lipoprotein (HDL), Triglycerides (TGs), waist circumference and prostatic parameters that is prostate volume, prostate specific antigen (PSA), uroflometry, International prostate symptom score (IPSS) were assessed at baseline, after 3 and 6 months follow-up. Further appropriate statistical tests were applied for comparison of parameters among groups.

Results: Patients receiving no treatment for Metabolic Syndrome were having most deranged prostatic parameters as compared to patients without Metabolic Syndrome or patients with Metabolic Syndrome receiving treatment for same. Further patients receiving treatment for Metabolic Syndrome and alpha adrenergic blocker were having better clinical profile than patients of alpha adrenergic blocker alone.

Conclusions: These findings show probable link between Metabolic Syndrome and worse prostatic profile. Metabolic Syndrome must be looked for and treated in patients of Benign Prostatic Hyperplasia. Metabolic derangements must not be overlooked and must be treated accordingly.
\end{abstract}

Keywords: Benign prostatic hyperplasia, Metabolic Syndrome, Prostatic profile

\section{INTRODUCTION}

Benign prostatic hyperplasia (BPH) is a common medical ailment of elderly and middle-aged males. Due to lack of uniform diagnostic criteria exact prevalence of $\mathrm{BPH}$ could not be estimated but it may range from $40-50 \%$ at 50 years may rise upto $80 \%$ in elderly. Prostate is a chestnut shaped gland weighing about $20 \mathrm{gm}$ which lies below the bladder encircling the upper part of urethra. It is divided into three zones i.e. Anterior Zone, Peripheral Zone and Transition
Zone. Transition zone is considered as site for development of BPH.

There are no uniform criteria to define $\mathrm{BPH}$ and it varies from urologist to pathologist. From pathology point of view $\mathrm{BPH}$ is a microscopic diagnosis characterized by cellular proliferation of the stromal and epithelial elements of the prostate. ${ }^{1}$ To the urologist, it represents a constellation of lower urinary tract symptoms (LUTS) that develop in the male population in association with aging 
and prostatic enlargement, presumably caused by bladder outlet obstruction. ${ }^{2}$ From urodynamic study point of view, elevated voiding pressure and a low urinary flow rate in the absence of other disease processes that cause bladder outlet obstruction is characteristic of $\mathrm{BPH} .{ }^{3}$ Whatever be the definition or point of view the quality of life of patient suffers a lot.

Serum prostate-specific antigen (PSA) levels and prostate volume are positively correlated. ${ }^{4}$ There is no strict guideline to establish diagnosis of BPH on the basis of size of prostate, some authorities consider prostate volumes exceeding $40 \mathrm{~cm}^{3}$ supports the diagnosis. The sign and symptoms of BPH include LUTS, poor bladder emptying, urinary retention, detrusor instability, hematuria, and renal insufficiency, but majority of patient usually present with LUTS. $^{5}$

Aetio-pathogenesis of BPH is not clear yet, there are multiple factors which are considered for causal association. Pathologic changes occur in the local autonomous nervous system, the local endocrine system, epithelial-stromal interactions, luminal/epithelial interactions and infiltrating cells of the immune system.

Prostate receives both adrenergic and cholinergic innervations of which alpha-1-adrenoreceptor is the primary determinant for urethral resistance causing outflow obstruction and LUTS. ${ }^{6}$ This establishes the rationale for using alpha-1-adrenoreceptor blocker in medical management of $\mathrm{BPH}$.

Prostate has always been target of sex steroids and prostatic stromal cells have all machinery for peripheral generation of biologically active sex-steroid hormones. With advancing age prostatic testosterone level decreases, but ratio of prostatic estradiol/testosterone rises (peripheral conversion by aromatase). Estrogen generated in this manner is responsible for stromal growth, smooth muscle cell differentiation. Considering this fact anti-estrogens and especially aromatase inhibitors have been used for medical treatment of LUTS caused by BPH. There are other factors also which may directly or indirectly contribute to $\mathrm{BPH}$.

Metabolic Syndrome started initially as a concept rather than a diagnosis. ${ }^{7}$ Metabolic Syndrome is defined by a constellation of an interconnected physiological, biochemical, clinical, and metabolic factors that directly increases the risk of atherosclerotic cardiovascular disease (ASCVD), T2DM and all-cause mortality. ${ }^{8}$ Multiple attempts have been made to define Metabolic Syndrome by different authorities such as National Cholesterol Education Programme Adult Treatment Panel III (NCEP ATP III), the World Health Organization (WHO), the European Group for the study of Insulin Resistance (EGIR), American Association of Clinical Endocrinologists (AACE) and the International Diabetes Federation (IDF). ${ }^{9-12}$
The criteria of IDF are:

- Central Obesity (defined as waist circumference)

- $\quad$ Raised Triglycerides: $>150 \mathrm{mg} / \mathrm{dl}$.

- $\quad$ Raised blood pressure: $>130 / 80 \mathrm{mmHg}$.

- $\quad$ Raised fasting plasma glucose: $>100 \mathrm{mg} / \mathrm{dl}$.

- Reduced HDL level: $<50 \mathrm{mg} / \mathrm{dl}$ in females and $<40 \mathrm{mg} / \mathrm{dl}$ in males.

Out of these, central obesity plus any other two factors establish the diagnosis of Metabolic Syndrome.

Prevalence of Metabolic Syndrome ranges between 10$84 \%$, depending on the region, urban or rural environment, demographic characteristics (sex, age, race, and ethnicity) of the population studied, and the definition of the syndrome used. ${ }^{13,14}$ The primary culprit is central obesity. Adipocytes which once were considered depot for fat storage, it's actually a endocrine tissue releasing multiple factors in regulated manner. It includes Interleukin (IL-1), Leptin, Tumor Necrosis Factor (TNF-alpha), adiponectin, procoagulants, angiotensin. Adiponectin having beneficial effect that it enhances insulin sensitivity, oxidizes lipids and protective to blood vessels. Leptin, which is thinning hormone, its levels are reduced in case of obesity. Resistin having increased level in obesity may be responsible for insulin resistance. These numerous molecules released from adipocytes seems to contribute to development of insulin resistance which may progress to full blown diabetes mellitus and dyslipidemia, rise in blood pressure, chronic inflammatory state which may enhance atherosclerosis.

\section{Metabolic Syndrome and BPH are they Co-related?}

Answer to this question is not absolute and various plausible hypothesis are proposed. Certain epidemiological studies state patients with higher waist circumference tend to have more chances of surgically treated BPH as compared to their non-obese counterpart, individuals with higher waist to hip ration tend to have more risk of developing BPH, Body Mass Index (BMI) and waist-to-hip ratio were significant predictors of moderate to severe LUTS. ${ }^{15-17}$ Considering these evidences, it seems that obesity significantly predisposes patients to a higher risk of BPH/LUTS. While a lot of studies showed positive link between obesity and BPH, it was not same with dyslipidemia, the evidence was not convincing to establish link between dyslipidemia and $\mathrm{BPH}$. However in case of insulin resistance, compensatory hyperinsulinemic state, patients tend to have larger prostate volume, more chances of suffering from BPH/LUTS. ${ }^{18,19}$ The hypertension showed little bit similar trend as shown by insulin resistance.

To conclude, it appears that Metabolic Syndrome or its individual components possibly predispose patients to a higher risk of BPH/LUTS. The molecular basis of this finding is still being explored and numerous explanations are proposed e.g. hyperinsulinemia induced autonomic 
hyperactivity, impaired nitric oxide synthatase activity, pro-inflammatory state etc.

\section{METHODS}

The present prospective study was conducted in collaboration of the Department of Pharmacology and Department of Urology and associated Sir Sunder Lal Hospital (SSLH), Banaras Hindu University over a period ranging from February 2014 to June 2015. The patients were explained the nature and intent of the study and informed consent was then obtained. This study was approved by Institute Ethical Committee (IEC).

All the patients who came to Urology OPD for urinary complaints and diagnosed with Benign Prostatic Hyperplasia and started treatment with alpha blocker for the first time were enrolled for study. Detailed history and clinical examination is conducted with special emphasis on Digital Rectal Examination and Metabolic History. Severity of patient's urinary symptoms was assessed by International Prostate Symptom Score (IPSS). Anthropometric parameters like height, weight, waist circumference and hip circumference were taken and from these Body Mass Index (BMI) and Waist Hip Circumference Ratio (WHCR) were calculated. Transabdominal ultrasound was done to assess Prostate Volume and Post Voidal Urinary Retention (PVRU). Blood Samples were taken for Serum Prostate Specific Antigen (PSA), Fasting Blood Glucose, Urea, Creatinine and Lipid Profile all the investigations were carried out by Centre for Clinical Investigation, SSL Hospital. To assess the severity of urinary obstruction, Uroflowmetric Studies were conducted in Urology Department and Voided Volume and Maximum Urinary Flow Rate (Qmax) were noted.

For the diagnosis of Metabolic Syndrome, ATP III guidelines were used according to which any three of the following five parameters should be positive:

- Waist Circumference $>40$ inch

- $\quad$ Triglycerides $>150 \mathrm{mg} / \mathrm{dl}$

- $\quad$ HDL-C $<40 \mathrm{mg} / \mathrm{dl}$

- $\quad$ Blood Pressure $>130 / 85 \mathrm{mmHg}$

- Fasting Blood Glucose $>110 \mathrm{mg} / \mathrm{dl}$ (includes diabetes)

All these patients were divided into three groups based on the presence of metabolic syndrome and its treatment

- Without metabolic syndrome

- With metabolic syndrome without treatment

- With metabolic syndrome with treatment

The profile of prostatic health in terms of symptoms scale and objective changes in size as well as urodynamic parameters was studied and correlated with changes in any of the metabolic parameters. Based on the kind of prostate regression therapy or symptomatic therapy the outcomes were analyzed.

\section{Follow up study}

All patients were re-examined after 3 and 6 months on similar parameters and necessary laboratory and radiologic studies were repeated.

\section{Inclusion criteria}

- Ambulatory and noncritical.

- $\quad$ Age range- 40yrs-70yrs.

- Diagnosed Benign Prostatic Hyperplasia patients on conservative therapy with alpha blocker only.

\section{Exclusion criteria}

- Non ambulatory and critically ill Patients.

- Recent history of Acute Urinary Retention or Urinary Tract Infection.

- $\quad$ Systolic blood pressure more than $160 \mathrm{~mm} \mathrm{Hg}$

- $\quad$ Fasting Blood Glucose more than $200 \mathrm{mg} / \mathrm{ml}$.

- Suspicion of prostatic carcinoma.

- $\quad$ History of previous surgical treatment for BPH.

- On 5 alpha reductase inhibitor therapy for BPH.

\section{Statistical analysis}

To compare Prostatic Parameters among groups Repeated Measure Multifactorial ANOVA with Bonferroni as post hoc test was applied. Statistical analysis was done using SPSS.16.0 version and results were analyzed accordingly. A probability level $<0.05$ was considered to be statistically significant.

\section{RESULTS}

This study was conducted between February 2014 and May 2015 during that period 147 cases were enrolled and 93 turned up in the first and second follow up after 3 and 6 months. Further 93 cases were divided into three groups, i.e. Group 1: Patients of BPH with no Metabolic Syndrome $(n=70)$, Group 2: Patients of $\mathrm{BPH}$ with Metabolic Syndrome receiving no treatment $(n=9)$, Group 3: Patients of BPH with Metabolic Syndrome receiving treatment $(n=14)$. The mean age of patients was 60.5 years, mean waist circumference $35.2 \mathrm{~cm}$ with mean body mass index $24.4 \mathrm{~kg} / \mathrm{m}^{2}$.

Repeated measure multifactorial ANOVA was applied on different prostatic parameters to determine whether there was a statistical significance between three different types of groups based on metabolic syndrome and its therapy for helping relieve prostatic symptoms. The independent variable included a between-subjects variable, the metabolic syndrome, and within-subject variable, repeated measures of 0,3 and 6 months. The dependent variables were the prostatic parameters (Prostate Volume, Serum 
PSA, IPSS score, PVRU, Voided Volume and Qmax). A significance level of 5\% was utilized for this analysis. Mauchly's test of sphericity and Greenhouse-Geisser correction was applied in every prostatic parameter Results for model assumptions of normality, homogeneity of covariance, and linearity were satisfactory.

Table 1 represents effect of metabolic syndrome and its therapy on prostate volume in BPH patients. There was not a statistically significant interaction in the amount of prostate volume change between metabolic group type and test time, $\mathrm{F}(2.07,93.4)=0.006, \mathrm{p}=0.995$. The result of main effect with time was also not significant, F (1.03, 93.43) $=0.03, p=0.864$, tests of between-subject effects has also given a non-significant main effect in the metabolic group type, $\mathrm{F}(2,90)=1.575, \mathrm{p}=0.213$. It indicates there was no significant change in prostate volume with time in 3 and 6 months follow up and also there is no significant difference between different group's prostate volumes, the trend of prostate volume change was also similar between different groups.

Table 1: Effect of metabolic syndrome and its therapy on prostate volume in $\mathrm{BPH}$ patients.

\begin{tabular}{|c|c|c|c|}
\hline \multicolumn{4}{|c|}{ Prostate volume (ml) $($ Mean \pm SD) } \\
\hline Groups & $\begin{array}{l}\text { At start of } \\
\text { study }\end{array}$ & $\begin{array}{l}\text { After } 3 \\
\text { months }\end{array}$ & $\begin{array}{l}\text { After } 6 \\
\text { months }\end{array}$ \\
\hline Group 1 & $41.17 \pm 18.59$ & $41.50 \pm 18.06$ & $41.37 \pm 18.34$ \\
\hline Group 2 & $52.22 \pm 18.63$ & $52.55 \pm 18.36$ & $54.89 \pm 18.55$ \\
\hline Group 3 & $44.00 \pm 19.19$ & $44.07 \pm 19.20$ & $44.14 \pm 19.31$ \\
\hline \multirow{3}{*}{$\begin{array}{l}\text { Repeated } \\
\text { measure } \\
\text { multifact } \\
\text { orial } \\
\text { ANOVA }\end{array}$} & \multirow{2}{*}{$\begin{array}{l}\text { Within } \\
\text { subjects } \\
\text { effects }\end{array}$} & Time & $\begin{array}{l}F=0.406 \\
P=0.546\end{array}$ \\
\hline & & Time* groups & $\begin{array}{l}F=0.268 \\
P=0.788\end{array}$ \\
\hline & $\begin{array}{l}\text { Between } \\
\text { subjects } \\
\text { effects }\end{array}$ & Groups & $\begin{array}{l}F=1.786 \\
P=0.174\end{array}$ \\
\hline \multirow{2}{*}{\multicolumn{2}{|c|}{$\begin{array}{l}\text { Post HOC test } \\
\text { (Bonferroni) (P value) }\end{array}$}} & I*II & - \\
\hline & & II*III & - \\
\hline
\end{tabular}

$*=\mathrm{p}=0.05$ to $0.01, * *=\mathrm{p}=0.01$ to $0.001, * * *=\mathrm{p}=<0.001,-$ $=\mathrm{p}=>0.05$

Table 2 shows effect of metabolic syndrome and its therapy on Prostate Specific Antigen (PSA) in BPH patients. There was a statistically significant interaction in the amount of PSA change between metabolic group type and test time, $\mathrm{F}(2.68,120.8)=7.272, \mathrm{p}=<0.001, \eta^{2}=0.91$. The result of main effect with time was also significant, $F$ $(1.34,120.8)=9.035, \mathrm{p}=.001, \eta^{2}=0.139$, a moderate effect size was evident. Tests of between-subject effects has also given significant main effect in the metabolic group type, $\mathrm{F}(2,90)=4.761, \mathrm{p}=0.01$. This has got following implications: Significant difference between different group's PSA was found. It was in the order of $3>2>1$, subsequently there was a significant change in PSA with time in 3 and 6 months follow up for group 3. The trend of prostate volume change with time was significantly different between different groups. PSA was significantly reduced in group 3 as compared to group 1 and 2 .

Table 2: Effect of metabolic syndrome and its therapy on Prostate Specific Antigen (PSA) in BPH patients.

\begin{tabular}{|c|c|c|c|}
\hline \multirow{2}{*}{ Groups } & \multicolumn{3}{|c|}{$\begin{array}{l}\text { Prostate specific antigen (ng/ml) } \\
(\text { Mean } \pm \text { SD) }\end{array}$} \\
\hline & $\begin{array}{l}\text { At start of } \\
\text { study }\end{array}$ & $\begin{array}{l}\text { After } 3 \\
\text { months }\end{array}$ & $\begin{array}{l}\text { After } 6 \\
\text { months }\end{array}$ \\
\hline Group 1 & $2.55 \pm 1.58$ & $2.50 \pm 1.54$ & $2.52 \pm 1.51$ \\
\hline Group 2 & $4.25 \pm 1.07$ & $4.24 \pm 1.08$ & $4.23 \pm 1.09$ \\
\hline Group 3 & $3.14 \pm 2.30$ & $2.78 \pm 1.86$ & $2.65 \pm 1.77$ \\
\hline \multirow{3}{*}{$\begin{array}{l}\text { Repeated } \\
\text { measure } \\
\text { multifactorial } \\
\text { ANOVA }\end{array}$} & \multirow{2}{*}{$\begin{array}{l}\text { Within } \\
\text { subjects } \\
\text { effects }\end{array}$} & Time & $\begin{array}{l}F=9.035 \\
P=0.001\end{array}$ \\
\hline & & $\begin{array}{l}\text { Time* } \\
\text { groups }\end{array}$ & $\begin{array}{l}\mathrm{F}=7.272 \\
\mathrm{P}=<0.001\end{array}$ \\
\hline & \multicolumn{2}{|l|}{$\begin{array}{l}\text { Between } \\
\text { subjects } \\
\text { effects }\end{array}$} & $\begin{array}{l}F=4.761 \\
P=0.01\end{array}$ \\
\hline \multirow{3}{*}{$\begin{array}{l}\text { Post HOC test } \\
\text { (Bonferroni) (P } \\
\text { value) }\end{array}$} & \multicolumn{2}{|l|}{ I*II } & $* *$ \\
\hline & \multicolumn{2}{|l|}{ II*III } & - \\
\hline & \multicolumn{2}{|l|}{ I*III } & - \\
\hline
\end{tabular}

Table 3: Effect of metabolic syndrome and its therapy on International Prostate Symptom Score (IPSS) in BPH patients.

\begin{tabular}{|c|c|c|c|c|}
\hline \multirow[b]{2}{*}{ Groups } & \multicolumn{4}{|c|}{ IPSS (Mean \pm SD) } \\
\hline & \multicolumn{2}{|c|}{$\begin{array}{l}\text { At start of } \\
\text { study }\end{array}$} & $\begin{array}{l}\text { After } 3 \\
\text { months }\end{array}$ & $\begin{array}{l}\text { After } 6 \\
\text { months }\end{array}$ \\
\hline Group 1 & \multicolumn{2}{|c|}{$18.37 \pm 4.48$} & $9.95 \pm 2.67$ & $8.47 \pm 2.33$ \\
\hline Group 2 & \multicolumn{2}{|c|}{$24.55 \pm 6.59$} & $16.66 \pm 3.87$ & $15.44 \pm 3.32$ \\
\hline Group 3 & \multicolumn{2}{|c|}{$20.41 \pm 8.49$} & $11.50 \pm 4.31$ & $9.67 \pm 3.49$ \\
\hline \multirow{3}{*}{$\begin{array}{l}\text { Repeated } \\
\text { measure } \\
\text { multifactorial } \\
\text { Anova }\end{array}$} & \multirow{2}{*}{\multicolumn{2}{|c|}{$\begin{array}{l}\text { Within } \\
\text { subjects } \\
\text { effects }\end{array}$}} & Time & $\begin{array}{l}F=324.33 \\
P=<0.001\end{array}$ \\
\hline & & & $\begin{array}{l}\text { Time* } \\
\text { groups }\end{array}$ & $\begin{array}{l}\mathrm{F}=0.476 \\
\mathrm{P}=0.641\end{array}$ \\
\hline & \multicolumn{3}{|c|}{$\begin{array}{l}\text { Between } \\
\text { subjects } \\
\text { effects }\end{array}$} & $\begin{array}{l}F=14.37 \\
P=<0.001\end{array}$ \\
\hline \multirow{3}{*}{\multicolumn{2}{|c|}{$\begin{array}{l}\text { Post HOC test } \\
\text { (Bonferroni) (P value) }\end{array}$}} & \multicolumn{2}{|c|}{ I*II } & $* * *$ \\
\hline & & \multicolumn{2}{|c|}{ II*III } & $* *$ \\
\hline & & \multicolumn{2}{|c|}{ I*III } & - \\
\hline
\end{tabular}

Table 3 elucidate effect of metabolic syndrome and its therapy on International Prostate Symptom Score (IPSS) in BPH patients. There was no statistically significant interaction in the amount of IPSS change between metabolic group type and test time, $\mathrm{F}(2.20,96.9)=0.476$, $\mathrm{p}=0.64$. The result of main effect with time was significant with $\mathrm{F}(1.10,96.9)=324.3, \mathrm{p}=<0.001$, $\eta^{2}=0.787$, a large effect size was evident. Tests of betweensubject effects has also given significant main effect in the metabolic group type, $\mathrm{F}(2,88)=14.37, \mathrm{p}=<0.001$, $\eta^{2}=0.246$. This leads to following conclusion, there is 
significant difference between different group's IPSS was found. It was in the order of $2>3>1$. There was a significant change in IPSS with time in 3 and 6 months follow up for all 3 groups. It decreased in all three groups. The trend of IPSS change with time was not significantly different between different groups.

Table 4 shows effect of metabolic syndrome and its therapy on Post Void Residual Urine

(PVRU) in BPH patients. There was no statistically significant interaction in the amount of PVRU change between metabolic group type and test time, F (2.32, $104.4)=2.261, p=0.101$. The result of main effect with time was significant with $\mathrm{F}(1.16,104.4)=105.6, \mathrm{p}=$ $<0.001, \eta^{2}=0.540$, a moderate effect size was evident. Tests of between-subject effects has also given significant main effect in the metabolic group type, $F(2,90)=8.77$, $p=<0.001, \eta^{2}=0.163$. It means ther is significant difference between different group's PVRU was found. It was in the order of $2>1>3$. There was a significant change in PVRU with time in 3 and 6 months follow up for all 3 groups. PVRU was found to be decreased in all 3 groups. The trend of PVRU change with time was not significantly different between different groups.

Table 4: Effect of metabolic syndrome and its therapy on Post Void Residual Urine (PVRU) in BPH patients.

\begin{tabular}{|c|c|c|c|c|}
\hline \multirow[b]{2}{*}{ Groups } & \multicolumn{4}{|c|}{ PVRU (ml) (Mean \pm SD) } \\
\hline & \multicolumn{2}{|c|}{$\begin{array}{l}\text { At start of } \\
\text { study }\end{array}$} & $\begin{array}{l}\text { After } 3 \\
\text { months }\end{array}$ & $\begin{array}{l}\text { After } 6 \\
\text { months }\end{array}$ \\
\hline Group 1 & \multicolumn{2}{|c|}{$71.09 \pm 32.21$} & $45.90+23.05$ & $37.41 \pm 21.03$ \\
\hline Group 2 & \multicolumn{2}{|c|}{$85.55 \pm 27.83$} & $65.55 \pm 22.50$ & $58.56 \pm 19.89$ \\
\hline Group 3 & \multicolumn{2}{|c|}{$42.50 \pm 24.86$} & $28.00 \pm 20.34$ & $19.64 \pm 16.61$ \\
\hline \multirow{3}{*}{$\begin{array}{l}\text { Repeated } \\
\text { measure } \\
\text { multifacto } \\
\text { rial } \\
\text { Anova }\end{array}$} & \multirow{2}{*}{\multicolumn{2}{|c|}{$\begin{array}{l}\text { Within } \\
\text { subjects } \\
\text { effects }\end{array}$}} & Time & $\begin{array}{l}F=105.67 \\
P=<0.001\end{array}$ \\
\hline & & & $\begin{array}{l}\text { Time* } \\
\text { groups }\end{array}$ & $\begin{array}{l}F=2.26 \\
P=0.101\end{array}$ \\
\hline & \multicolumn{2}{|c|}{$\begin{array}{l}\text { Between } \\
\text { subjects } \\
\text { effects }\end{array}$} & Groups & $\begin{array}{l}F=8.77 \\
P=<0.001\end{array}$ \\
\hline \multirow{3}{*}{\multicolumn{2}{|c|}{$\begin{array}{l}\text { Post HOC test } \\
\text { (Bonferroni) (P } \\
\text { value) }\end{array}$}} & \multicolumn{2}{|l|}{$I^{*} \mathrm{II}$} & - \\
\hline & & \multicolumn{2}{|l|}{ II*III } & $* *$ \\
\hline & & \multicolumn{2}{|l|}{ I*III } & $* *$ \\
\hline
\end{tabular}

Table 5 depicts effect of metabolic syndrome and its therapy on Voided Volume in BPH patients. There was no statistically significant interaction in the amount of voided volume change between metabolic group type and test time, $\mathrm{F}(2.75,121)=2.58, \mathrm{p}=0.061$. The result of main effect with time was significant with $F(1.37,121)=28.6$, $\mathrm{p}=<0.001, \eta^{2}=0.245$, a moderate effect size was evident. Tests of between-subject effects has given non-significant main effect in the metabolic group type, $\mathrm{F}(2,88)=2.38$, $\mathrm{p}=0.098$. These findings show, no significant difference between different group's voided volume was found. There was a significant change in voided volume with time in 3 and 6 months follow up for all 3 groups in voided volume was found to be increased in all 3 groups. The trend of voided volume change with time was not significantly different between different groups.

\section{Table 5: Effect of metabolic syndrome and its therapy} on VOIDED VOLUME in BPH patients.

\begin{tabular}{|c|c|c|c|}
\hline \multirow[b]{2}{*}{ Groups } & \multicolumn{3}{|c|}{ Voided volume (ml) $($ Mean \pm SD) } \\
\hline & $\begin{array}{l}\text { At start of } \\
\text { study }\end{array}$ & After 3 months & $\begin{array}{l}\text { After } 6 \\
\text { months }\end{array}$ \\
\hline Group 1 & $325.95 \pm 48.14$ & $337.35 \pm 49.29$ & $340.49 \pm 47.50$ \\
\hline Group 2 & $319.77 \pm 25.44$ & $334.77 \pm 19.24$ & $337.67 \pm 18.00$ \\
\hline Group 3 & $353.16 \pm 129.78$ & $380.16 \pm 109.47$ & $386.83 \pm 104.00$ \\
\hline \multirow{3}{*}{$\begin{array}{l}\text { Repeated } \\
\text { measure } \\
\text { multifactori } \\
\text { al anova }\end{array}$} & \multirow{2}{*}{$\begin{array}{l}\text { Within } \\
\text { subjects } \\
\text { effects }\end{array}$} & Time & $\begin{array}{l}F=28.62 \\
P=<.001\end{array}$ \\
\hline & & Time*groups & $\begin{array}{l}F=2.58 \\
P=0.06\end{array}$ \\
\hline & $\begin{array}{l}\text { Between } \\
\text { subjects } \\
\text { effects }\end{array}$ & Groups & $\begin{array}{l}F=2.38 \\
P=0.09\end{array}$ \\
\hline \multirow{3}{*}{\multicolumn{2}{|c|}{$\begin{array}{l}\text { Post HOC test } \\
\text { (Bonferroni) (P } \\
\text { value) }\end{array}$}} & & - \\
\hline & & & - \\
\hline & & & - \\
\hline
\end{tabular}

Table 6: Effect of metabolic syndrome and its therapy on Qmax in BPH patients.

\begin{tabular}{|c|c|c|c|}
\hline \multirow[b]{2}{*}{ Groups } & \multicolumn{3}{|c|}{ Qmax $(\mathrm{ml} / \mathrm{s})(\mathrm{Mean} \pm \mathrm{SD})$} \\
\hline & $\begin{array}{l}\text { At start of } \\
\text { study }\end{array}$ & $\begin{array}{l}\text { After } 3 \\
\text { months }\end{array}$ & $\begin{array}{l}\text { After } 6 \\
\text { months }\end{array}$ \\
\hline Group 1 & $10.08 \pm 2.15$ & $12.49 \pm 1.51$ & $13.28 \pm 1.37$ \\
\hline Group 2 & $9.04 \pm 1.01$ & $11.24 \pm 0.47$ & $11.95 \pm 0.16$ \\
\hline Group 3 & $11.20 \pm .85$ & $13.24 \pm 0.65$ & $14.17 \pm 0.61$ \\
\hline \multirow{3}{*}{$\begin{array}{l}\text { Repeated } \\
\text { measure } \\
\text { multifactorial } \\
\text { Anova }\end{array}$} & \multirow{2}{*}{$\begin{array}{l}\text { Within } \\
\text { subjects } \\
\text { effects }\end{array}$} & Time & $\begin{array}{l}\mathrm{F}=306.5 \\
\mathrm{P}=<0.001\end{array}$ \\
\hline & & $\begin{array}{l}\text { Time* } \\
\text { groups }\end{array}$ & $\begin{array}{l}\mathrm{F}=0.751 \\
\mathrm{P}=0.496\end{array}$ \\
\hline & \multicolumn{2}{|l|}{$\begin{array}{l}\text { Between } \\
\text { subjects } \\
\text { effects }\end{array}$} & $\begin{array}{l}F=5.324 \\
P=0.007\end{array}$ \\
\hline \multirow{3}{*}{$\begin{array}{l}\text { Post HOC test } \\
\text { (Bonferroni) (P } \\
\text { value) }\end{array}$} & \multicolumn{2}{|l|}{ I*II } & - \\
\hline & \multicolumn{2}{|l|}{ II*III } & $* *$ \\
\hline & \multicolumn{2}{|l|}{ I*III } & - \\
\hline
\end{tabular}

Table 6 represents effect of metabolic syndrome and its therapy on Qmax in BPH patients. There was no statistically significant interaction in the amount of Qmax change between metabolic group type and test time, $\mathrm{F}$ $(2.37,104.3)=0.751, p=0.496$. The result $\eta^{2}=0.777, a$ large effect size was evident. Tests of between-subject effects has given non-significant main effect in the metabolic group type, $\mathrm{F}(2,88)=5.324, \mathrm{p}=0.007$, $\eta^{2}=0.108$, small effect size was seen. The findings show significant difference between different group's Qmax was found, it is in the order of $3>2>1$. There was a significant change in Qmax with time in 3 and6 months follow up for 
all3 groups. Qmax was found to be increased in all 3 groups. The trend of Qmax change with time was not significantly different between different groups.

\section{DISCUSSION}

In all 93 cases of BPH sustained at 03 and 06 months evaluation, more than two third of these did not display clinical features of Metabolic Syndrome. There were 23 cases out of 93, which is less than one third, who qualified for Metabolic Syndrome. More than half of these were receiving treatment for diabetes, dyslipidemia and in some hypertension. Overall occurrence of Metabolic Syndrome in patients of $\mathrm{BPH}$ is higher than general prevalence rate in population. ${ }^{20}$ It is also being found that the prevalence of Metabolic Syndrome was higher in patients with severe LUTS.

The Prostate Volume of cases having Metabolic Syndrome was on higher side than in those without metabolic syndrome. There was very little decrease in Prostate Volume and no difference was seen in the volume changes among different groups.

The PSA level was significantly lowest in non Metabolic Syndrome group. BPH cases with Metabolic Syndrome had significantly increased PSA level. Anti-diabetic treatment associated in group 3 shows relatively lower PSA level than those in group 2 without treatment. Antidiabetic treatment in cases with Metabolic Syndrome (group 3) was associated with a declining trend in PSA level, this observation requires to be taken cognizance of. Correction of Metabolic Syndrome including use of Statins and in some cases ACE inhibitors and Thiazide diuretics, should inhibit inflammatory and immune processes and can explain observed decline in PSA profile. Men who regularly take thiazide diuretics had lower PSA levels, as also men taking NSAIDs, statins or ACE inhibitors. ${ }^{21,22}$ Metformin has been found to be negatively correlated with PSA level. ${ }^{23}$ Effect of antidiabetic, hypolipidemic and antihypertensive treatment on prostate and PSA, therefore is known to be beneficial.

International Prostate Symptom Score comprises symptomatic contributions of mechanical obstruction, inflammation and bladder irritability. Patient with untreated Metabolic Syndrome had significantly higher starting IPSS scores, partly greater Prostate Volume may be responsible for mechanical obstruction. The scores are however, disproportionately higher. This points to contribution of inflammation and bladder hyperreactivity, which would be more in untreated Metabolic Syndrome. The IPSS score declined in all groups but again decline of IPSS in Metabolic Syndrome cases not receiving antidiabetic treatment is inferior to other two groups. It is documented that IPSS score and prostate volume were significantly higher in patients with prostatic inflammation. ${ }^{24}$ The finding, although statistically not significant, supports treatment of Metabolic Syndrome to get better relief in Prostate Symptoms.
Post voidal Retention of Urine (PVRU) volumes were particularly low in persons with Metabolic Syndrome on diabetic treatment. In contrast, largest PVRU was seen in untreated Metabolic Syndrome. Even without difference in prostate volume, BPH cases without Metabolic Syndrome and BPH cases with treated Metabolic Syndrome exhibit such significant difference in PVRU. It has been observed that Total Prostate Volume and Post Voidal Retention were significantly higher in subjects with Metabolic Syndrome. ${ }^{25}$ The values of treated and untreated Metabolic Syndrome group are also significantly different. The observation clearly supports the role of ongoing antidiabetic or antihypertensive therapy in reducing PVRU. The most prominent decline at 3 months was in cases not having Metabolic Syndrome. The presence of Metabolic Syndrome may compromise efficacy of alpha blockers in reducing PVRU. Voided volume of urine is not different between groups with and without Metabolic Syndrome. Cases receiving anti-diabetic and antihypertensive treatment have relatively larger recorded Voided Volume. That may be caused by diuretics and improvement in renal physiology. However, the Voided Volume depends on sensitivity for voiding. Relatively larger Voided Volume in diabetes receiving treatment may alternatively indicate decreased sensitivity for voiding.

All the groups had improved Qmax following alpha blocker administration however such improvement was insignificantly less marked in untreated metabolic syndrome cases. The examination of Qmax (i.e. maximum urinary flow rate) revealed the untreated metabolic syndrome cases having lesser flow rates than those receiving anti-diabetic treatment. This difference due to Metabolic Syndrome in BPH apparently calls for antidiabetic management.

\section{CONCLUSION}

As this was an observational study, after dividing and comparing 93 patients, the significant differences at baseline were observed. At the outset cases with untreated metabolic syndrome had worst International Prostate Symptom Score, Prostate Volume Residual Urine, Qmax and Prostate Specific Antigen profile. The cases of Benign Prostate Hyperplasia and Metabolic Syndrome receiving specific treatment only had worse PSA profile but had even lesser Post Voidal Urinary Residual Volume than cases without metabolic syndrome. The findings of this study have been corroborated with reported larger studies also commenting upon possible mechanisms for worse $\mathrm{BPH}$ prognosis with metabolic syndrome and improvement with therapy. The common symptomatic Alpha Blocker treatment available to all groups appeared to have unaffected efficacy in presence or absence of metabolic syndrome. The finding support relation of metabolic syndrome to worsening of BPH pathology. It is found that metabolic syndrome must be diagnosed and treated in cases of BPH. It may be even worthwhile to address metabolic disturbances that fall short of metabolic syndrome definition. This can be investigated and treated 
as improved quality conservative care of Benign Prostate Hyperplasia. A research need may be perceived on link of metabolic syndrome and hyperplasia accruing in prostate for conceptualizing any definitive therapeutics.

\section{Funding: No funding sources}

Conflict of interest: None declared

Ethical approval: The study was approved by the Institutional Ethics Committee

\section{REFERENCES}

1. Strandberg JD. Comparative pathology of benign prostatic hyperplasia. In: Lepor $\mathrm{H}$, ed. Prostatic Diseases. Philadelphia: WB Saunders; 2000:329-343.

2. Shapiro E, Lepor H. Pathophysiology of clinical benign prostatic hyperplasia.Urol Clin North Am. 1995;22:285-90.

3. Nitti VW. Diagnosis of obstructive uropathy. In: Lepor H, ed. Prostatic Diseases. Philadelphia: WB Saunders; 2000:197-209.

4. Roehrborn CG, Pickens GJ, Carmody T. $3^{\text {rd }}$. Variability of repeated serum prostate-specific antigen (PSA) measurements within less than 90 days in a well-defined patient population. Urology. 1996;47:5966.

5. Jepsen JV, Bruskewitz RC. Clinical manifestations and indications for treatment. In: Lepor $\mathrm{H}$, ed. Prostatic Diseases. Philadelphia: WB Saunders; 2000:127-142.

6. Lepor H, Shapiro E. Characterization of alpha1 adrenergic receptors in human benign prostatic hyperplasia. J. Urol. 1984;132:1226-9.

7. Shaw JE, Chisholm DJ. Epidemiology and prevention of type 2 diabetes and the metabolic syndrome, Medical Journal of Australia. 2003;7(179):379-83.

8. Grundy SM, Cleeman JI, Daniels SR. Diagnosis and management of the metabolic syndrome: an American Heart Association/NationalHeart, Lung, and Blood Institute scientific statement, Circulation. 2005;17(112):2735-52.

9. Cleeman JI. Executive summary of the third report of the National Cholesterol Education Program (NCEP) expert panel on detection, evaluation, and treatment of high blood cholesterol in adults (adult treatment panel III), Journal of the American Medical Association, 2001;285(19):2486-97.

10. Alberti KG, Zimmet PZ. Definition, diagnosis and classification of diabetes mellitus and its complications. Part 1: diagnosis and classification of diabetes mellitus provisional report of a WHO consultation, Diabetic Medicine, 1998;7(15):539-53.

11. Balkau B, Charles MA. Comment on the provisional report from the WHO consultation: European Group for the Study of Insulin Resistance (EGIR), Diabetic Medicine. 1999;5(16):442-3.

12. Einhorn. Endocr Pract. American College of Endocrinology Position Statement on the Insulin Resistance Syndrome. 2003;9(No. 3):236-52.
13. Desroches S, Lamarche B. The evolving definitions and increasing prevalence of the metabolic syndrome, Applied Physiology, Nutrition and Metabolism. 2007;1(32):23-32.

14. Kolovou GD, Anagnostopoulou KK, Salpea KD, Mikhailidis DP. The prevalence of metabolic syndrome in various populations. The American Journal of the Medical Sciences. 2007;6(333):362-71.

15. Giovannucci E, Rimm EB, Chute CG, Kawachi I, Colditz GA, Stampfer MJ, et al. Obesity and benign prostatic hyperplasia. Am J Epidemiol. 1994;140:9891002.

16. Dahle SE, Chokkalingam AP, Gao YT, Deng J, Stanczyk FZ, Hsing AW. Body size and serum levels of insulin and leptin in relation to the risk of benign prostatic hyperplasia.J Urol. 2002;168:599-604.

17. Seim A, Hoyo C, Ostbye T, Vatten L. The prevalence and correlates of urinary tract symptoms in Norwegian men: the HUNT study. BJU Int. 2005;96:88-92.

18. Hammarsten J, Högstedt B. Hyperinsulinemia as a risk factor for developing benign prostatic hyperplasia. Eur Urol. 2001;39:151-8.

19. Joseph MA, Harlow SD, Wei JT. Risk factors for lower urinary tract symptoms in a population-based sample of African American men. Am J Epidemiol. 2003;157:906-14.

20. Sawant A, Mankeshwar R, Shah S, Raghavan R, Dhongde G, Raje H, et al. Prevalence of Metabolic Syndrome in Urban India. Cholesterol. 2011.

21. Chang SL, Harshman LC, Presti JC. Impact of common medications on serum total prostate-specific antigen levels: analysis of the National Health and Nutrition Examination Survey. J Clin Oncol. 2010;28(25):3951-7.

22. Cyrus-David MS, Weinberg A, Thompson T, Kadmon D. The effect of statins on serum prostate specific antigen levels in a cohort of airline pilots: a preliminary report. J Urol. 2005;173(6):1923-5.

23. Jayalath V, Ireland C, Augustin L, Stephanie N, Mirrahimi A, De Souza R, et al. The Association Between Serum Prostate-Specific Antigen and Glycemic Index, Glycemic Load, and Metformin in Individuals with Diabetes: a Cross-sectional Analysis. The FASEB Journal. 2015;1(29):406.8.

24. Robert G, Descazeaud A, Nicolaïew N, Terry S, Sirab $\mathrm{N}$, Vacherot F, et al. Inflammation in benign prostatic hyperplasia: a 282 patients' immunohistochemical analysis. Prostate. 2009;69:1774-80.

25. Park YW, Kim SB, Kwon H, Kang HC, Cho K, Lee $\mathrm{KI}$, et al. The relationship between lower urinary tract symptoms/benign prostatic hyperplasia and the number of components of metabolic syndrome. Urology. 2013;82(3):674-9.

Cite this article as: Panwar V, Pandey BL, Dwivedi US, Singh A. Comparative clinical profile of patients of Benign Prostatic Hyperplasia (BPH) with and without Metabolic Syndrome: a prospective observational study. Int J Basic Clin Pharmacol 2017;6:2452-8. 